\title{
Praktiese kerkwees in die nuwe Suid-Afrika
}

T F J Dreyer

Universiteit van Pretoria

\begin{abstract}
The praxis of the church in the new South Africa

Political and social changes in the new South Africa will impose a new praxis with far reaching consequences, especially for the Afrikaans speaking churches. Although it is still premature to define the new praxis the church has to be prepared to accept the challenges. A few studies in this regard have already been published. This paper is an attempt to draw certain guidelines, based on available research done in this area.
\end{abstract}

\section{INLEIDING}

Die 'Nuwe Suid-Afrika' is stelselmatig besig om sedert April 1994 op alle terreine van die samelewing gestalte te kry. Die volle konsekwensies daarvan het nog nie werklik tot op die grondvlak van ons alledaagse lewe en van ons kerkwees deurgedring nie. Baie veranderinge moet eers voltrek word voordat ons die werklike impak van die nuwe situasie kan peil. Nuwe strukture vir plaaslike owerhede, wat op die gemeenskapslewe 'n dramatiese effek gaan hê, moet nog in plek kom. Regstellende aksies en die Heropbou en Ontwikkelingsprogram moet nog vanaf die tekenbord omskep word in daadwerklike verandering. Die nuwe onderwysbedeling met één sentrale departement en beleid, wat primêr daarop gerig sal wees om agterstande in agtergeblewe gemeenskappe uit te wis, sal eers vanaf 1995 gestalte begin kry. Gewysigde subsidieformules vir welsynsdienste, waarvan die Nederduitsch Hervormde Kerk afhanklik is, moet nog uitgespel word. Verhoogde belasting waarmee al die aksies befonds moet word, sal nog in die toekoms sy tol eis.

Om dus nou al te praat van kerkwees in die 'Nuwe Suid-Afrika', is eintlik prematuur, omdat ons nog nie die volle omvang daarvan vir die kerk kan peil nie. Daarmee wil ek nie beweer dat ons maar op die ou trant moet voortgaan nie, maar juis dat die samelewing en die omstandighede waarbinne ons kerk sal moet wees, so dramaties gaan verander, dat die Nederduitsch Hervormde Kerk deur die tyd agterhaal sal word as ons nie nou dringend gaan besin oor hoe ons die nuwe situasie tegemoet moet gaan nie.

\footnotetext{
* Lesing gehou tydens 'n simposium van die Nederduitsch Hervormde Kerk van Afrika en die Hervormde Kerk in Suidelike Afrika oor die roeping van die kerk in die 'nuwe Suid-Afrika' op 28 Oktober 1994.
} 
Onder die 'Nuwe Suid-Afrika' verstaan ek dus nie 'n statiese feitelikheid nie maar 'n wordingsproses waarvan ons nou slegs die breë kontoere kan identifiseer. Dat dit radikaal anders daar sal uitsien as dit wat ons aan gewoond is, is egter gewis, en juis daarom sal dit van die kerk 'n soepel ingesteldheid en 'n voortdurende bereidheid tot aanpassing vra om binne 'n nuwe gegewenheid sy roeping te vervul. As daar oor die praktiese kerkwees in die nuwe situasie gepraat word, verstaan ek onder 'kerk' in die besonder die Nederduitsch Hervormde Kerk van Afrika, omdat 'n mens nie oor praktiese kerkwees kan praat los van 'n bepaalde kerkorganisasie nie. Dit gaan dus uiteindelik om die vraag hoe die Hervormde Kerk prakties kerk moet wees.

In tye van sosiale en kulturele omwentelinge is dwarsdeur die kerkgeskiedenis telkens teruggevra na die verbindende, rigtinggewende en onveranderlike boodskap en na die identiteit van 'n dinamiese geloofsgemeenskap wat hieruit moet lewe in veranderende tye. In sulke tye voel individue en gemeenskappe dikwels dat hulle polities, ekonomies, moreel, maar ook kerklik-teologies vasgeval het; dat die ou standaard antwoorde en oplossings vir vrae net nie meer genoegsaam is nie. Die samehangende veilige wêrelde spat uitmekaar, soos onder andere Bybelse eksegese en sosiale werklikheid, monolitiese bedieningspatrone en uitdyende pluraliteit. Wat doen predikante dan? Daar is gewoonlik drie geykte moontlikhede:

* of hulle verlaat die bediening;

* óf hulle regresseer, dit is 'n terugval in 'n verdediging van die oue, van die gearriveerde teologie; gooi wal teen die inkomende gety; noem dit allerlei name; restoureer in plaas van transformeer, dit wil sê maak die krake reg en pas die metode aan - dit is vir die kerk 'n doodloopstraat;

* óf hulle sien in die vasgeloopte situasie 'n uitdaging, 'n opening vir nuwe moontlikhede van omgaan met die teks en die tradisie, daarom 'n nuwe klem op 'n dinamiese gemeente wat op plaaslike vlak die paslike antwoorde bied, maar uitgedink in dialoog met groter ekumeniese gemeenskappe van geloof. Dit doen hulle nie vanuit 'n vlak optimisme nie, maar vanuit wat Arbuckle (1991) noem 'n 'grieving for a change'.

Om die nuwe situasie as 'n uitdaging te sien, is egter vir die meeste Afrikaners en lidmate van die Hervormde Kerk nie so maklik en vanselfsprekend nie. Die kerk kan homself maklik van sy lidmate vervreem en predikante kan hulle geloofwaardigheid inboet deur, met verbygaan van mense se vrese en pyn, gewoon na die nuwe situasie as 'n uitdaging te verwys. Burger (1994:85) beweer dat die veranderende situasie in Suid- 
Afrika in die prediking van die kerk binne drie moontlike perspektiewe of raamwerke aan die orde gestel sou kon word, naamlik 'n materialistiese-, filosofiese- of 'n teologiese perspektief.

* Materialisties is die perspektief van waaruit die gebeure beleef word deur bevoorregte kerkmense. Hier is die kernvraag: 'Wat gaan ek behou?'; 'Sal ek die situasie oorleef met genoeg om van te leef, genoeg om my kinders 'n lewe te gee?'

* Filosofies is die perspektief waar mense lotgevallig oor die gebeure oordeel. Uitsprake soos: 'Dit moes kom'; 'Daar is niks wat ons daaraan kon doen nie'; 'Die geskiedenis neem sy loop', is tipies van hierdie raamwerk.

* Teologies is dan die perspektief dat God in beheer is van die lotgevalle van mense en gemeenskappe, daarom kan ons bly glo dat die toekoms vir ons oop is. Die geloof sal sigbaar word in hardnekkige hoop. Die Christelike hoop is hier van kardinale belang, maar dan in die sin dat egte Bybelse hoop 'n oopheid vir lyding en die negatiewe kant van die lewe hand aan hand gaan. Ons sal gelowiges moet leer om te treur en hulle help verstaan dat pyn en lyding nie noodwendig vyande is nie. 'n Oopheid vir lyding en die vermoë om daarmee te leef, is die poort na egte Bybelse hoop.

Burger is reg as hy kies vir ' $n$ teologiese perspektief, maar indien die kerk in die prediking en pastoraat die bestaan van die eerste twee perspektiewe ignoreer, gaan 'n groot getal lidmate die prediking as wêreldvreemd beleef omdat hulle die preek selektief verstaan binne hulle werklikheid (Pieterse 1990:104). Ek is van oortuiging dat die kerk in die prediking en pastoraat gelowiges moet begelei na 'n teologiese perspektief, maar dan nie deur eersgenoemde twee te ignoreer of as dwaas te etiketteer nie, maar juis deur die erkenning van die werklikheid van sulke perspektiewe, gelowiges te begelei tot ' $n$ teologiese verstaan. Eers wanneer die prediking en pastoraat die treur en pyn van baie gelowiges in die nuwe situasie verstaan, dit as eg ervaar en verwoord, kan mense gelei word tot nuwe hoop en uitsig. Vanuit hierdie pastorale invalshoek, wat in al die geloofshandelinge van die kerk moet manifesteer, kan vervolgens na enkele fasette van praktiese kerkwees gekyk word.

\section{SOEKE NA 'N KONTEKSTUELE HERMENEUTIEK}

Die kerk is in die wêreld, maar die wêreld is ook in die kerk. Met hierdie stelling word die uitdaging aan die hermeneutiese debat van ons tyd omlyn. Binne die dialek- 
tiese spanningsveld van hierdie twee werklikhede, moet die gemeente in sy kerkwees sy identiteit soek en vind. Gemeentelede wat na 'n preek kom luister, wil deur die liturgie en prediking veral 'n aandeel kry aan hulle eiendomlike 'community of character' (Müller 1992:28). Pastoraat, kategese en diakonaat moet hulle daarin versterk, maar die liturgie en die prediking is die eintlike plekke, in 'n korporatiewe sin dié plek waar hierdie eiendomlike karakter geartikuleer en gevier moet word. Long (1989:84) het al beklemtoon dat die preek die Christen se identiteit moet beklemtoon. Die hele bediening van die kerk sal hierdie identiteit moet formuleer, korrigeer en verhelder. Om dit te kan doen moet die konteks van die Bybelse teks, maar ook die konteks waarin die kerk leef, ten volle verdiskonteer moet word. In die lig daarvan bepleit Müller (1992: 27) 'n hermeneutiek op die intervlak tussen eksegese en sosiale analise. Die verkondiging soek na 'n dinamiese hermeneutiek wat 'n proses genereer waardeur die kerk en die wêreld nuwe weë in die Woord ontdek om God, hulleself, hulle wêreld en hulle situasie te verstaan. Dit is juis op hierdie kruispunt waar 'n verantwoorde sosiale hermeneutiek, gebou op 'n wetenskaplike sosiale analise vir hom noodsaaklik is. So 'n hermeneutiese benadering moet uitmond op 'n hermeneutiek ten dienste van die gemeentelike verkondiging. Müller (1992:31-33) stel onder andere die volgende vereistes aan so 'n ekklesionome hermeneutiek:

* Dit moet sin en hoop ontsluit vir die private sowel as die sosiale lewe. Dit moet ' $n$ pastorale aksent van besorgdheid en sorg laat hoor.

* Dit sal 'n hermeneutiek van die dialoog vereis. Dit is 'n dialoog op die openbare markplein van 'n pluralistiese samelewing, waar die Christelike boodskap nie meer die monopolie of selfs die voorrang het nie.

* Dit moet 'n hermeneutiek van identifikasie wees wat die vrae van die geloofsgemeenskap na 'n nuwe identiteit in 'n nuwe gemeenskap artikuleer en presiseer.

* Dit moet 'n hermeneutiek van verbeelding en fantasie wees. Die beloftes van die teks moet transformerend die verbeelding van die gemeente wek.

Hierdie gedagtes van Müller is op sigself ' $n$ mondvol en stel die kerk in sy teologiebeoefening voor geweldige uitdagings. 'n Mens se eerste reaksie is om daarvoor terug te deins. Kontekstuele hermeneutiek wek tradisioneel by die Hervormde kerk negatiewe konnotasies. Dit was juis die kontekstuele hermeneutiek wat aanleiding gegee het tot die teologie van bevryding en rewolusie, waarteen die kerk in die verlede verset ge- 
bied het, omdat dit ontaard het in 'n politieke teologie. Is die volkskerkgedagte, soos verwoord in ons kerklike geskrifte, nie juis in 'n sekere sin neerslag van 'n kontekstuele hermeneutiek nie? Die Hervormde Kerk het in 'n poging om die evangelieboodskap binne die Afrikanervolk inheems te laat word, juis kontekstuele hermeneutiek benadruk. In die kerk se vereenselwiging met die vryheidstrewe van die Afrikaner se geskiedenis, het die Hervormde Kerk die identiteit van die geloofsgemeenskap geartikuleer. Miskien het die kerk in die verlede toegelaat dat die konteks van die Afrikanervolk (ook politieke strukture) so dominant geword het in sy 'kontekstuele hermeneutiek' dat dit voorwaarde geword het vir die voortbestaan van die kerk. Met die ineenstorting van politieke strukture wat die Afrikanervolk se identiteit omlyn en geartikuleer het, ervaar die geloofsgemeenskap 'n bestaan in 'n vakuum en vind die Hervormde Kerk dit moeilik om in die verkondiging in ' $n$ nuwe bedeling die identiteit van die gemeente te verwoord. Die bekende neiging kom weer na vore om, uit vrees vir die uitdaging, die klem te laat val op die geestelike en die innerlike ten koste van die sosiale relevansie. Die Bybelboodskap moet teen besmetting gevrywaar word. So 'n houding sou noodlottig wees vir die kerk. Palmer (1981:60vv) het oortuigend aangetoon watter selfvernietigende gevolge die konsentrasie op die 'privaat-geestelike' vir die kerke in die Verenigde State van Amerika gehad het. Bowendien laat die kerk deur so 'n houding die lidmate se verwarring en onsekerheid toeneem, omdat die kerk in die prediking nalaat om hulle te begelei tot 'n nuwe identiteit.

Hoe gevaarlik die hermeneutiese onderneming ook mag lyk - die kerk kan nie daarvoor terugdeins nie. Ons sal hermeneuties, op die voetspoor van die riglyne wat neergelê is, die geloofsgemeenskap moet begelei na 'n nuwe identiteit. Hierdie nuwe identiteit waartoe 'n kontekstuele hermeneutiek die kerk in sy bediening moet bring, bestaan myns insiens daarin dat die Hervormde Kerk enersyds nie kan los kom van 'n geskiedenis waar die kerk in die besonder vir die Afrikaner, binne dié se kultuurmilieu, kerk wou wees en moet bly nie. Die kerk sal ook die kerkvolk hermeneuties moet help om die 'plek en die rol van die Afrikanergeloofsgemeenskap binne 'n multikulturele samelewing te definieer. Die blote feit dat politieke strukture die omlyning van die Afrikaner as volk laat vervaag het, maak die teologiese uitgangspunt onderliggend aan die volkskerkgedagte, naamlik dat die kerk, om waarlik kerk te kan wees, 'inheems' moet word binne die kultuur van die bepaalde groep tot wie die kerk gerig word, nie ongeldig nie. Andersyds sal daar ook opnuut besin moet word hoe die kerk in die apostolaat na die omringende wêreld buite die kerk gerig gaan word, omdat tradisionele strukture en afgrensings van groepe en rasse verdwyn het. 


\section{HOMILETIESE IMPLIKASIES}

Firet (1974:131v) het die term agogie weer op die tafel geplaas toe hy dit voorgestel het as oorkoepelende term vir die totale pastorale arbeid en optrede. Oor die term kan 'n mens verskil, maar oor die saak en die basiese argument kan daar nie veel meningsverskil wees nie. Agogie, leiding, of begeleiding is waaroor die kerklike bediening tot 'n groot mate gaan. Die prediking het ook 'n duidelike agogiese moment. In die verlede is die agogiese moment op ' $n$ intellektuele wyse hanteer. 'Agogie was tot 'n hoë mate gelyk gestel aan verbale advies wat op ' $n$ min of meer wettiese wyse aán die gemeente deurgegee is by wyse van die prediking, kategese, huisbesoek, sinodale besluite, ensovoorts' (Burger 1994:88). Die mate van sukses wat hierdie manier van begeleiding in die verlede gehad het, kan waarskynlik toegeskryf word aan die feit dat die mikro- en makrosisteme van die samelewing waarbinne die kerk hom bevind het, hierdie advies onderbou en help vestig het: 'n Christelike owerheid, met wetgewing wat Christelike waardes beskerm het; Christelik-nasionale onderwys het die raamwerk van denke gevorm; isolasie van ander godsdienste het kompeterende menings geëlimineer. In ' $n$ nuwe bedeling het hierdie sisteme wat die begeleiding van die kerk bevestig het, tot 'n groot mate weggeval.

Binne die Hervormde Kerk is die prediking totaal oorvra. Die prediking moes alles doen en vermag. In die vorige bedeling met sy onderbouende strukture, het dit nog tot ' $n$ mate geslaag, maar binne 'n nuwe bedeling moet ons weer nuut dink. Effektiewe leer in die geloofsgemeenskap vind nie volgens ' $n$ intellektuele model plaas nie, maar deur wat genoem sou kon word sosialisering. Leersituasies moet geskep word waar hierdie dinge gemodelleer word en in die praktiese lewe van die geloofsgemeenskap ingeoefen kan word. Dit gaan nie bloot om die saaklike bepaling en artikulering van sekere korrekte waardes nie, maar om die vorming van 'n deugsame geloofsgemeenskap. Die prediking sal moet uitmond in geleenthede binne gemeenteverband waar hierdie identiteit van die gemeente in groepsverband gestalte kry. Naas die prediking sal daar ' $n$ werklike koinoniale en diakonale atmosfeer moet groei, wat die ideale ruimte vir verandering en identiteitsvorming bied. Die geloofsgemeenskap sal steeds meer as 'n alternatiewe gemeenskap na vore moet tree.

Teen dié agtergrond sal die prediking, as dit reg aan die agogiese wil laat geskied, werklikheidsbetrokke, relevant en konkreet moet wees. Die insette van preekbesprekingsgroepe, ook by die voorbereiding van die preek, word dringender. Prediking sal nuwe hoop moet gee. 'Die hoop van die geloofsgemeenskap word gebou, nie deur prediking wat primêr aansegging of vermaning is nie, maar prediking waarin die herinnering aan 'n ander dieper werklikheid lewend gehou word deur die oorvertel van die verhale van die geloofsgemeenskap' (Burger 1994:90). Hoop bou en teer op herrinneringe 
wat van buite die situasie kom en extra nos aan ons gegee moet word. Die prediking kan slegs daarin slaag om hierdie agogiese rol te vervul indien dit onderbou word deur ander sisteme binne die lewe van die gemeente.

\section{PASTORALE IMPLIKASIES}

Op die terrein van die pastoraat was daar reeds pogings om die situasie binne die Nuwe Suid-Afrika te verdiskonteer. Müller (1991:186) praat van die noodsaaklikheid van 'n eko-hermeneutiese pastorale sorg. In sy terminologie dui die begrip 'hermeneuties' op die element van verstaan, terwyl 'eko' verwys na die wydste moontlike eko-sistemiese netwerk van onderliggende sistemiese interaksie. Sy hermeneutiese sirkel veronderstel dat in alle interpretasie daar ' $n$ resiproke verwantskap tussen die dele en die geheel bestaan. Die doel van 'n hermeneutiese pastoraat is om die relasie tussen die verhaal van mense en die Verhaal van God te vind. Die premisse is egter dat die verhaal van mense alleenlik binne die ekologiese raamwerk verstaan kan word en slegs met die totale ekologiese raamwerk in gedagte, kan die Verhaal van God binne daardie spesifieke konteks verstaan word. Hy toon ook die belangrikheid van die erkenning van die bestaan van bepaalde vooroordele by mense aan as gevolg van die tradisie waarbinne hulle opgegroei het. Ons sal in die pastoraat ook bereid moet wees om te praat oor mekaar se vooroordele. Hy bepleit dat pastoraat nie slegs in 'n terapeutiese kompartement geplaas moet word nie, maar dat die kerk besprekingsgroepe oor verskillende onderwerpe in die samelewing moet fasiliteer, ook gesprekke tussen konflikterende groepe.

Uit hierdie paar opmerkings is dit in die eerste plek duidelik dat die geykte vorm van pastoraat tydens huisbesoek en die besondere pastoraat nie voldoende is om die eise van die nuwe situasie te akkommodeer nie. Ons moet pastoraat veel wyer sien as geleentheid tot diskussie en gesprek in groepsverband. Die kerk sal die geleentheid moet bied aan mense om hulle vooroordele te verwoord, dit te erken om saam binne 'n totaal nuwe konteks die betekenis van die Verhaal van God te ontdek. Soos in die prediking sal ons in die pastoraat mense moet begelei om as geloofsgemeenskap te soek na 'n nuwe identiteit. Hulle vrese, pyn en hoop sal in 'n nuwe konteks aangespreek moet word.

Via die pastoraat sal daar aandag gegee moet word om weer die familiale struktuur van die geloofsgemeenskap te aktiveer. In gesins- en groepsverband, sal funksies wat vroeër deur ander instellings waargeneem is, weer deel van ons koinoniale verantwoordelikheid moet uitmaak. 'n Omgee- en dienskarakter sal weer binne die geloofsgemeenskap gestalte moet kry. Die eie taal en kultuur, asook bepaalde waardes, sal binne die groepverband gekoester moet word. Selfs ontspanning, vermaak en sportaktiwiteite sal waarskynlik in 'n groter mate in kleiner groepsverband plaasvind. 


\section{DIAKONALE IMPLIKASIES}

Dit is waarskynlik op die terrein van die diakonaat waar die Hervormde Kerk die mees ingrypende veranderinge sal moet aanbring. Diakonale versorgingsinstellings, wat in die verlede grotendeels via subsidies van die owerheid bedryf is, sal drastiese inkortings beleef. Vanuit sy eie finasiële bronne is dit vir die kerk haas onmoontlik om die tehuise vir bejaarde- en kindersorg op dieselfde basis te kan bedryf. Diakonale versorgingsfunksies sal afgewentel moet word na gemeentelike vlak. Nuwe subsidieformules gaan ons waarskynlik forseer om die konsep van bejaardeversorging drasties te verander. Selfversorgende bejaardes sal binne gemeente- of wyer gemeenskapsverband versorg moet word deur hulle solank as moontlik in hulle eie behuising te behou. Ondersteunende dienste sal deur familie, vriende, die plaaslike gemeente se diensgroepe en dienssentrums, gelewer moet word. Die plaaslike gemeente se geboue sal meer en meer 'n gemeenskapsentrum moet word. Behalwe kleuterskole wat al by baie kerkkomplekse bedryf word, kan dit uitgebrei word na 'n naskoolsentrum vir kinders van ouers wat albei werk, asook 'n sentrum vir dagmoeders vanuit die eie gemeente se geledere. Bejaardes wat nog aktief is kan by so 'n sentrum op talle wyses benut word. Werkloosheid en armoede is twee vraagstukke wat ook op plaaslike vlak hanteer sal moet word.

Alhoewel die verandering traumaties sal wees, is daar dalk vir die kerk op die lang duur iets goeds in geleë. Diakonia en koinonia is twee kante van dieselfde muntstuk en is 'n onlosmaaklike deel van kerkwees. Waar die koinonia lewend is, is die diakonia die spontane reaksie, veral wanneer die nood van die ander sigbaar naby aan jou kom, is die appél en bereidheid om barmhartigheid te bewys, soveel groter.

\section{MISSIONÊRE IMPLIKASIES}

Die tradisionele sendingbeleid van die Hervormde Kerk is geformuleer in 'n situasie waarbinne duidelike omlyning van volks- en kultuurgroepe in staatsvorme, wetgewing en samelewingsverbande uitdrukking gevind het. Met die aanbreek van die 'nuwe' Suid-Afrika het hierdie skerp omlyning weggeval. Binne 'n eenheidstaat vervaag die begrip 'volk'. 'n Handves vir menseregte gaan primêr uit van die regte van die individu wat beskerm moet word. Groepsregte, veral die van kultuurgroepe, word hoogstens by wyse van die reg van vryheid van assosiasie erken.

Soos reeds hierbo vermeld, beteken dit nie noodwendig dat omdat wetlike beskerming van volke en/of kulruurgroepe verdwyn het, dit impliseer dat die bestaan van sodanige groeperinge gaan verdwyn nie. Die geskiedenis van Oos-Europa het juis aangetoon hoe sterk etniese-, kulturele- en godsdienstige groeperinge se kragte in die samelewing is. Soos reeds betoog moet die kerk daarom voortgaan om binne 'n bepaalde kultuurgroep 'inheems' te wees en te word. Die ideaal, soos verwoord in 
Artikel III, naamlik: ' $\ldots$ die vorming van volkskerke onder die verskillende volksgroepe ...' kan op grond van ons teologiese uitgangspunt onverkort gehandhaaf word, trouens in so verre as wat volke verkies om hulle kultuurverband in die nuwe situasie te handhaaf. Die opleiding van predikante om sendingwerk onder die verskillende swart volksgroepe te doen, moet voortgaan. Die ideaal van die vestiging en uitbouing van volkskerke onder die verskillende volksgroepe, lyk teologies gesien nog steeds die mees sinvolle. Evagelisasiewerk om die eie volksgenote wat van die kerk vervreemd geraak het, weer te evangeliseer, kan nie gestaak word nie.

Bo en behalwe hierdie sendingaktiwiteit sal die kerk egter ook rekening moet hou met die feit dat daar, naas die tradisionele volks- en kultuurgroeperinge, in die Nuwe Suid-Afrika 'n groepering aan die ontstaan is wat hulleself nie aan ' $n$ bepaalde kultuurgroep gekoppel wil sien nie. Dit is veral binne die stedelike komplekse waar sulke 'grys' groeperinge sigbaar word. Of daar uit hierdie multikulturele en multi-etniese sameflansing in die toekoms 'n nuwe 'kultuurgroep' gaan ontwikkel, is op hierdie stadium moeilik voorspelbaar. Die gegewenheid is egter dat daar so 'n multikulturele groepering aan die groei is. Die kerk kan in sy apostolêre verantwoordelikheid nie by hierdie werklikheid verbykyk nie. Gemeentes waar sulke gemeenskappe op hulle voorstoep is, sal met die evangelie daarheen moet uitreik. Die taal wat vir die meeste toeganklik is, sal waarskynlik Engels wees. Bekeerlinge sal ook moeilik binne die bestaande gemeentes van die Hervormde Kerk of die Hervormde Kerk in Suidelike Afrika opgeneem kan word, sonder dat dit weer die identiteit van die bestaande gemeentes sal aantas. In lyn met ons teologiese denke oor die kerk, sal die Hervormde Kerk hierdie arbeidsterrein moet betree met die openheid dat dit ' $n$ totaal nuwe bedieningstrategie sal vra. Die resultaat van hierdie sendingaksie sal myns insiens noodwendig moet lei tot die daarstelling van ' $n$ tweestroombeleid, waar daar naas die bestaande gemeentes, nuwe gemeentes gestig, of selfs eventueel 'n nuwe kerk gevorm moet word. Die taal van die bediening, liturgiese vormgewing, die gemeentelike lewe en aktiwiteite sal nuut bedink moet word om so ' $n$ multikulturele gemeenskap se eiesoortige behoeftes en omstandighede te akkommodeer. In 'n beginfase kan die sendingwerk in stedelike gebiede op ringsbasis aangepak word. Daar kan in ringsverband en selfs waar nodig ook in samewerking met die Hervormde Kerk in Suidelike Afrika, met benutting van bestaande kerkgeboue en fasiliteite, een gesamentlike nuwe sendinggemeente gevestig word. Die tyd sal leer of hierdie sendinggemeentes in die toekoms 'n eie karakter en kultuur sal ontwikkel wat die vestiging van 'n nuwe kerk noodsaak.

\section{EKUMENIESE IMPLIKASIES}

Op ekumeniese gebied het die 'nuwe' Suid-Afrika die isolasie verbreek. Die kerk moet die geleentheid benut om op internasionale vlak, maar ook op nasionale vlak nuwe 
ekumeniese verbande te vestig. In vorige referate word spesifiek oor die ekumene gehandel, daarom wil ek hier slegs die aandag daarop vestig dat op plaaslike vlak die nuwe situasie ons gaan dwing om uitdagings deur ekumeniese samewerking die hoof te bied. Soos reeds beredeneer, kan samewerking tussen die Hervormde Kerk en die Hervormde Kerk in Suidelike Afrika op die sendingterrein nuwe moontlikhede open. Dit is egter veral op die terrein van die diakonaat waar dit noodsaaklik gaan word dat kerke, op plaaslike vlak in ekumeniese verband, sal moet saamwerk om bejaardeversorging, werkloosheid en armoede, die hoof te bied.

\section{EKONOMIESE IMPLIKASIES.}

In ons wildste drome kan ons nog nie bedink wat die impak van ekonomiese realiteite op die kerk sal wees nie. Behalwe vir die verandering van subsidieformules vir die instellings van die barmhartigheidsdiens, sal die bediening van die plaaslike gemeente, asook sinodale strukture, ernstig deur die ekonomie geraak word. Regstellende aksies, verhoogde belastings, afplatting in die lewenstandaard, werkloosheid en 'n waarskynlike verhoging in die inflasiekoers, gaan ook sy effek op die kerk hê. Gemeentes sal hulle begrotings drasties moet snoei, wat sal beteken dat talle luukses wat die kerk hom in die verlede veroorloof het, soos duur pastorieë, luukse kerkgeboue en administratiewe beamptes, sal verdwyn. Volledige versorgingspakette vir predikante gaan al moeiliker word. Die verskynsel van predikante met deelversorging wat ook op 'n ander wyse hulle lewenstog verdien gaan hom steeds meer voordoen. Op sinodale vlak sal steeds indringend gerasionaliseer moet word om heffings tot die absolute minimum te beperk. Die opleiding van predikante sal so gestruktureer moet word dat studente in hulle studieprogram die ruimte gebied moet word om naas die teologie ook ander loopbaanmoontlikhede te inkorporeer.

\section{SLOTOPMERKINGS}

Vir die Hervormde Kerk hou die 'nuwe' Suid-Afrika in dat daar oor die hele linie van die kerklike lewe nuut gedink sal moet word. Ons is geneig om daarvoor terug te deins, dit so lank as moontlik uit te stel, of te regresseer. So 'n houding moet ten alle koste vermy word. Moeilike tye en periodes van swaarkry was vir die kerk in die geskiedenis nog altyd heilsaam. Dit is tegelyk die geleentheid om van onnodige bagasie ontslae te raak, om weer oor die wesenlike te besin en om vanuit die geloof in God en sy toekoms met nuwe geloofskrag kerk te wees.

\section{Literatuurverwysings}

Arbuckle, G A 1991. Grieving for a change: A spirituality for refounding gospel communities. London: Chapman. 
Burger, C W 1994. Die agogiese moment in die prediking in 'n situasie van verandering. Praktiese Teologie in Suid-Afrika 9/1, 83-93.

Firet, J 1974. Het agogisch moment in het pastoraal optreden. Kampen: Kok.

Long, D J 1989. The witness of preaching. Westminister: John Knox Press.

Müller, B A 1992. Hermeneutiek op die intervlak tussen eksegese en sosiale analise. Praktiese Teologie in Suid-Afrika 7, 27-41.

Müller, J C 1991. Pastoral care in post-aprtheid South Africa. Praktiese Teologie in Suid-Afrika 6/2, 184-192.

Palmer, P J 1981. The company of strangers. New York: Crossroad. 